\title{
EVALUATION OF THE MODEL OF EDUCATION IN ISLAMIC ECONOMICS AND FINANCE: Empirical Evidences From Indonesia and United Kingdom
}

\author{
Euis Amalia \\ Islamic Economics, Syariah \& Law Faculty, \\ State Islamic University of Syarif Hidayatullah, Jakarta \\ euisamalia@yaboo.com
}

\begin{abstract}
This study attempts to evaluate the model of education in Islamic economics and finance that currently adopted in Indonesia and United Kingdom. The study employs the method of Analytic Network Process (ANP). This study decomposes the problem by way of undertaking in-depth interviews and questionnaires as preliminary steps to all stakes holders in these countries comprising practitioners, academicians, experts and users. In order to evaluate and measure these differences, pair-wise comparison is conducted followed by synthesis method to come up with appropriate solutions. The root of the problem comprises of internal and external, while the solution includes short term as well as long terms with strategic policy as the last outcome. The finding of this study demonstrates different results in every cluster of respective countries. Moreover, the findings reveal that quite a few challenges lie ahead in applying the best model to be used as teaching materials in these countries.
\end{abstract}

Keywords: Analytic Network Process, Islamic Economics, Education

\begin{abstract}
Abstrak
Penelitian ini akan mengevaluasi model pendidikan ekonomi dan keuangan Islam yang diadopsi dari Indonesia dan Inggris. Metode yang diterapkan adalab dengan Analytic Network Process (ANP), dimana wawancara mendalam dan kuesioner merupakan langkah awal yang diberikan kepada sejumlah praktisi, akademisi, para abli dan pengguna. Sebagai langkab untuk mengukurperbedaan tersebut dilakukan uji beda yang kemudian dilanjutkan melakukan sintesis untuk menemukan solusi. Akar masalabnya terdiri dari internal dan eksternal, sementara solusinya berbentuk kebijakan jangka pendek maupun jangka panjang. Hasil penelitian menunjukkan hasil yang berbeda pada masing-masing Negara. Selain daripada itu ada beberapa diantaranya sudab menerapkan model-model yang lebih baik dalam kegiatan pembelajarannya dan tentu saja penelitian ini merupakan salab satu yang menerapkan metode ANP dalam analisisnya yang perlu diterapkan pada sejumlah negara muslim.
\end{abstract}

Kata Kunci: Analytic Network Process, Ekonomi Islam, Pendidikan 


\section{Introduction}

The notion of Islamic economics thought basically derived from two modes. First, the ideal mode of thought through development of more comprehensive and holistic Islamic economics system. Second, pragmatism mode which is developing partial system or only one aspect, i.e, Islamic financial institution.

The fact shows that Islamic economic thought has developed into two modes; the first mode is comprehensive and holistic group who considers islamic economics as a whole system covering the theories and practices, and second mode is pragmatism group who believes that Islamic economics is only Islamic banking or Islamic financial institution. It is recorded that there are many different opinions among muslim thinkers who study Islamic economics with respect to their interpretation, approach and methodology in shaping the concept of Islamic economics. It is due to the difference background of their education, expertise and experience. Talking about pragmatism thought, some people might assume that limiting the understanding at only on Islamic banking or Islamic finance institution is too narrow, and it is acceptable because the fact shows that the Islamic economic system was built from banking system, while its theories were constructed later.

In Indonesia, the development of Islamic economics thought revealed that the second mode is the starting point which is marked by more rapid growth of Islamic banking industry followed by other islamic financial industries. Meanwhile, the theoritical and conceptual studies in shaping the comprehensive system appeared later and were shown by many writings from muslim scholars and by both formal dan informal academic programs with regard to this field. Yet undeniably, the develoment of Islamic banking is regarded as the gate for muslim thinkers to design Islamic economics as a system and a science.

The fact shows that Islamic Banking and Finance Industries have been growing fast. The annual report of Islamic Development Bank (IDB) estimated that the Islamic banking industries grew more than 15 percent per year, with more than 300 Islamic financial institutions spreading all over 75 countries, that might reach 500 
billion dollars of total asset. At year-end 2007, the total assets reached 660 billion dollars, and even over 1600 USD at the end of 2012.

According to Islamic Finance Country Index (IFCI) 2012, Iran was consistently filling the top position, followed by Malaysia in the second rank, and Indonesia stood at the $7^{\text {th }}$ rank, which is more sluggish than the previous year at the $4^{\text {th }}$ rank in 2011. Meanwhile, United Kingdom achieved the $11^{\text {th }}$ rank slightly better compared to previous year at the $15^{\text {th }}$. This Index (IFCI) demonstrates the ranking of the countries who have been developing Islamic finance especially the members of Organization of Islamic Conference (OIC). This index refers to several variables including number of muslim population, number of institutions involved in Islamic finance industries, size of Islamic finance asset, size of sukuk, education and culture, as well as regulatory and legal infrastucture.

Other European countries also have started with the opening of the Islamic financial institutions and major Islamic financial sukuk market. Europe's first sukuk was issued by Saxoni Anhalt in Germany, while Luxembourg as famous for its insurance industry has developed Islamic financial market.

Pertaining to Islamic finance, the role of British Muslims whose population more than 2 million people is very important in creating the phenomenon of Islamic finance in the country which is predominantly Christian. The establishment of the first Islamic bank, namely Islamic Bank of Britain (IBB) in 2004 was a systematic attempt by the British Muslim of Pakistani descent generally, Bangladesh and India. In addition to IBB, it's been standing four other Islamic banks namely Bank Gatehouse (2008), European Islamic Investment Bank (2005), Bank of London and Middle East (2007) and European Finance House (2008). In addition, conventional banks such as Lloyds TSB, Barclays, HSBC, etc. are also allowed to open a deposit account service shariah.

In just five years the UK has successfully established five Islamic banks with government support and the British parliament such as Financial Services Authority-FSA Finance Minister in 2006 which said that government committed for the development of Islamic banking and finance in the UK. In addition, Bank of England is 
also confident that there was no reason why Islamic financial products could not co-exist quite happily alongside the country's traditional financial services.

To support the Islamic financial transactions, the British government has finished its double issue stamp duties (double taxation) in Islamic financial transactions in 2003, accepting a contract of Murabahah and Mudarabah in the financial system and financial regulations in 2005 and, receiving Wakalah and diminishing Musharakah contract to complete the Islamic financial instruments that have been enacted in the UK. In a recent report, HM Treasury (finance ministry UK) and FSA titled: Legislative Framework for the Regulation of Alternative Finance Investment Bond (Sukuk) in October 2009 , stated that a number of tax provisions have been revised and the revision of the state finance law has been proposed to preserve the intention British government, the ministers of government. The following table describes the growth of Islamic banking asset in UK.

Table 1 The Growth of Islamic Banking Asset in United Kingdom

\begin{tabular}{lcrrrr}
\hline \multicolumn{7}{c}{ Islamic Banking Assets in UK* } & & \\
\hline Name of Bank & Year-end & $\mathbf{2 0 0 7 - 0 8}$ & $\mathbf{2 0 0 8 - 0 9}$ & $\mathbf{2 0 0 9 - 1 0}$ & \% change \\
\hline HSBC Amanah Finance & Sep-10 & 15194 & 16537 & 16699 & 1 \\
Bank of London and the & Dec-10 & 1196 & 1119 & 1115 & 0 \\
Middle East & Sep-10 & 570 & 698 & 524 & -25 \\
HSBC & Dec-10 & 648 & 555 & 284 & -49 \\
European Islamic & Dec-10 & 337 & 394 & 342 & -13 \\
Investment Bank & --- & 94 & --- & --- & --2 \\
Islamic Bank of Britain & QIB UK & 15 & 108 & 79 & -27 \\
Gatehouse Bank & Dec-09 & 18055 & 19411 & 19042 & -2 \\
\hline Total & & & &
\end{tabular}

Source: IFSL - Islamic Finance 2012 and The Banker

Like in other countries, Islamic banking and finance in Indonesia have significantly increased each year. It is recorded that the total assets of Islamic banking industry in November 2009 reached IDR 61.4 trillion and dramatically increased in 2010 by IDR 89 trillion. Asset growth sustained its upward momentum every year which is recorded 46.3\%. However, in 2009 the growth of Islamic banking was only $26.5 \%$ with a market share of $2.4 \%$ and rebound again with a growth of $46 \%$ in 2010 . High asset growth is characterized 
by a growing number of conventional banks to establish Islamic Banks and Syariah Business Unit. It is recorded that in 2011-2013, there were 11 Islamic Commercial Banks like Bank Muamalat, Bank Syariah Mandiri, Bank Rakyat Indonesia Syariah, Bank Mega Syariah, Bank Syariah Bukopin, and most recently Bank Victoria Syariah and Bank Panin Syariah. In addition, there were also 24 Islamic Business Units and 1920 offices of Islamic Banks as mentioned in the following table:

Table 2 Islamic Comercial Bank and Business Unit

\begin{tabular}{|c|c|c|c|c|c|c|c|}
\hline \multicolumn{8}{|c|}{ Islamic Commercial Banks } \\
\hline Year & 2007 & 2008 & 2009 & 2010 & 2011 & 2012 & August 2013 \\
\hline Number of Banks & 3 & 5 & 6 & 11 & 11 & 11 & 11 \\
\hline Bank's Offices & 401 & 581 & 711 & 1.215 & 1.401 & 1.745 & 1.920 \\
\hline \multicolumn{8}{|c|}{ Islamic Business Unit } \\
\hline Number of Islamic Business Unit & 26 & 27 & 25 & 23 & 24 & 24 & 24 \\
\hline Islamic Business Unit Offices & 196 & 241 & 287 & 262 & 336 & 517 & 554 \\
\hline
\end{tabular}

Pertaining to the issue of human capital, a research conducted by University of Indonesia in 2003 revealed that more than $90 \%$ of human capital in Islamic banking industries were from conventional background, who did not possess adequate knowledge in Islamic economics. It means that only $10 \%$ of them who possessed syariah educational background as mentioned in the following table:

Table 3 Education Background of Islamic Bank's Employee

\begin{tabular}{cccccccccc}
\hline Year & $\begin{array}{c}\text { High } \\
\text { School }\end{array}$ & D3 & $\begin{array}{c}\text { Bachelor of } \\
\text { Economics }\end{array}$ & $\begin{array}{c}\text { Bachelor of } \\
\text { Law }\end{array}$ & $\begin{array}{c}\text { Bachelor of } \\
\text { Political } \\
\text { Science }\end{array}$ & $\begin{array}{c}\text { Bachelor of } \\
\text { Agriculture }\end{array}$ & $\begin{array}{c}\text { Bachelor of } \\
\text { Civil } \\
\text { Engineering }\end{array}$ & $\begin{array}{c}\text { Bachelor } \\
\text { of Sharia }\end{array}$ & $\begin{array}{c}\text { Master } \\
\text { Degree }\end{array}$ \\
\hline 2009 & $6,2 \%$ & $18,7 \%$ & $38,0 \%$ & $6,2 \%$ & $5,2 \%$ & $4,9 \%$ & $7,6 \%$ & $9,1 \%$ & $4,1 \%$ \\
2008 & $5,3 \%$ & $12,1 \%$ & $39,1 \%$ & $7,2 \%$ & $6,8 \%$ & $6,3 \%$ & $9,2 \%$ & $8,6 \%$ & $5,3 \%$ \\
\hline
\end{tabular}

Source: Directorate of Islamic Banking, Bank Indonesia 2011

The lack of proper human capital is one of many factors that result in the slow growth of market share of Islamic banking in Indonesia. So slow that in 2013 it even didn't reach 5\%. In addition, to support the development of Islamic Banking, the number of human capital with integrated skills should be able to fulfill the needs of these industries. As shown by the table below: 
Table 4. The need and availability of Islamic Human Capital

\begin{tabular}{|c|c|c|c|c|c|c|c|c|c|c|c|}
\hline & \multicolumn{4}{|c|}{ Edistingden DamandSDMSgariah } & \multicolumn{3}{|c|}{ Suplier SDMSyaiah } & \multirow{2}{*}{$\begin{array}{c}\text { \%PdrutP. } \\
\text { Farmel }\end{array}$} & \multirow{2}{*}{$\begin{array}{l}\text { \%RelontP } \\
\text { NFamel }\end{array}$} & \multirow{2}{*}{$\begin{array}{c}\text { ExSuphly PN } \\
\text { Fammal }\end{array}$} & \multirow{2}{*}{$\begin{array}{l}\text { NowP.N } \\
\text { Fannd }\end{array}$} \\
\hline & 㽚 & us & EFS & Total & P.Famitit & P. Nonfamete & Total & & & & \\
\hline 2011 & 8512 & -443 & 465 & 8977 & 7,793 & 7,200 & 14,993 & 0.87 & Q13 & & \\
\hline 2012 & 13,12 & 425 & 533 & 13646 & $8.5 / 2$ & 7,920 & 16492 & 0.63 & 0.37 & & \\
\hline 2013 & 20200 & -407 & 611 & 20811 & 10287 & 9504 & 19,791 & 049 & Q51 & 1,000 & 6 \\
\hline 2014 & 31.118 & 391 & 701 & 31,819 & 13373 & 2366 & $25,7 B$ & 042 & $Q 5 B$ & 6,091 & $\ddot{B}$ \\
\hline 2015 & 4,937 & 35 & 804 & 48740 & 18722 & 17,297 & 36,019 & 038 & 062 & 22721 & 46 \\
\hline 2016 & 73,846 & 399 & 922 & $747 \circledast 8$ & 28083 & 25,946 & 54,029 & 038 & 062 & 20,739 & 5 \\
\hline 2017 & 113760 & 344 & 1,057 & 114817 & 44933 & 41,513 & क446 & 039 & Q61 & 28371 & 52 \\
\hline 2018 & 175,248 & 330 & 1,212 & 176,460 & 76386 & 70,573 & 146968 & 0.43 & 057 & 29501 & 3 \\
\hline 2019 & 2990 & 37 & 1,389 & 271,399 & 137,494 & 127,031 & 264525 & 0.51 & 049 & & \\
\hline 2000 & 415898 & 304 & 1,593 & 417,481 & 261,238 & 241,369 & 50259 & 063 & 0.37 & & \\
\hline
\end{tabular}

The statistical data of Bank Indonesia above describes the situation of human resources and industries. The huge gap between the industries and education sectors still occurred. The number of human resources cannot meet the number needed by the industries even though more universities have offered the Islamic economic programs. Unfortunately, the problem is not merely a matter of the number of human resources but also their competences which depend on the curriculum design in respective campus, that is not in line yet with what the industries need. Therefore, a mutual synergy between the industries and education sector is significant. As a matter of fact the UK also has similar problem. This situation will eventually lead to the need for institutions and Islamic financial markets to have experts and staffs who possess a background and proper competencies both in sharia and economics that might be able to address the necessity of the industries to design as well as innovate their products in order to compete with those of conventional banks.

Currently, many universities have offered the education of Islamic economics in the form of courses, concentrations as well as study program or department. In Indonesia, Islamic universities (PTA) are under the auspices of the Ministry of Religious Affairs (IHE) while public universities (PTU) are under the auspices of the Ministry of National Education. Each has specific characteristics in producing respective graduate profiles, especially in building the curriculum and learning material. At least this time in Indonesia there are about 45 higher academic institutions that have offered courses in the field of Islamic economics, Islamic banking and finance, as well as Islamic business law. Islamic economic studies have developed not 
only on the undergraduate level but also master's and doctoral levels, among others UIN / IAIN (PTA), UNAIR, UGM, IPB and UI (PTU).

Undeniably, the phenomenon of Islamic banks, Islamic finance and economics is not confined to the state of Muslim majority countries or countries of the third world. However, Islamic banks have become the new financial phenomenon in developed countries with a population of Muslim minorities. As in the countries of Asia and the Middle East, Islamic economics and finance is a financial phenomenon that is also growing rapidly in Europe continent. Countries such as England, France, Germany, the Netherlands and Luxemburg very excited to develop Islamic economics and finance. As initiated by Britain and France, now there are several universities that have Islamic economics study program, finance and banking at graduate level (master's and $\mathrm{PhD}$ ).

Islamic economics and finance education in Europe including the UK have developed rapidly. As the development of Islamic finance, this is primarily supported by the reputation of a university in European countries which listed as top ranking universities of the world. For example, Oxford University aged 800 years in addition to Cambridge University and London School of Economics who also gave birth to the names of Nobel economics winner. In the Netherlands there are Erasmus University and the Sorbonne University in France found that their reputation is worldwide and have several Muslim lecturers who are interested in reviewing the materials of Islamic finance and economics.

In the UK there are a number of universities that have post graduate of Islamic economics and banking programs with good ranking in the UK and the world. Meanwhile, in France there are two new universities having the same program. Moreover, in Britain there are number of centers of economic studies and Islamic finance. At Oxford University they have Oxford Center for Islamic Studies (OXCIS) which includes the study of Islamic finance at Cambridge University as well as the existing Center for Islamic Studies which is also conducting the workshop, a seminar on Islamic finance in cooperation with Middle East businessmen. Durham University in Durham also they have the Center for Islamic Economics and Finance. Cambridge University, Oxford University and Durham University is 
known as a university for the elite (nobility) in England and always perched on the top 5 ranking in the UK. Finally, the London School of Economics (LSE) and Harvard University each year has always held a workshop on Islamic economics and finance in London.

Since Indonesia and United Kingdom demanding huge human capital to meet the demand of industries whilst the huge gap between these institutions still occurred, this study attempts to analyze the education model that developed in these countries. Therefore, the problems of these studies are as follow: a) How these Countries apply the model of education in their universities; b) What are the problems in developing Islamic economic education of these countries?; c) What is the best solution to overcome the problems of developing Islamic economics education of these countries?; d) What is future strategy to overcome the gap between industry and university of these countries?

\section{Literature Review}

(Choudhury, 2011) argues that Islamic economics and finance possess different epistemology compared to capitalism. The Islamic economics and finance based on Maqasid Syariab while applying the concept of taubid and morality. He suggested that the application of Islamic economics and finance could not be separated but must be based on the concept of "tauhid". Integration approach in this matter is an essential to have better understanding.

(Ismail, 2012) conducted a study on education of Islamic economics and finance in United Kingdom. This study deliberates a preliminary investigation on major universities in UK offering Islamic economics and finance program for all degrees. This study is then supported by (Ahmed, 2008) who conducted the survey and interview and the finding reveals that there is huge opportunity of Islamic banking development since muslim inhabitants adopt Islamic banking product that comply to Islamic tenet. Therefore, there is an urgency of public education on this. Meanwhile, (AlKasrie, 2008) conducted a relevant study on comparative practices of education offering MBA program in universities across Asia, Middle East and European countries. She concluded that lecturers, teaching 
and evaluation method as well as research are playing significant part of educational support to broaden the knowledge of student in the area of Islamic economics and finance.

Similar study also conducted by (Muqarrabin, 2010) particularly in developing the curriculum and syllabus of Islamic economics for Muhammadiyah Universities using content analysis. This study basically recommends an integration approach of curriculum that can be applied to all universities. According to (Fauzi, 2005), there are challenges that Islamic banking industries must encounter; 1) the shift of customer from religion oriented to return oriented, 2) network and limited technology, 3) finding good debtors, 4) high risk of real sector or bankable debtors, 5) price competition, 6) limited CAR, 7) lack of capable human resources. This finding is supported by the finding of research conducted by University of Indonesia where $90 \%$ of employees of Islamic banks were not from Islamic economics background.

Meanwhile, (Agung and Sula, 2009), only 10\% of total human capital in Islamic banking and finance industries that coming from Sharia background while the rest absorbed from conventional industries. Within 4-5 years to come, the industries demanding more than 10,000 human capital. Therefore, academic institutions play significant role to meet the demand of industries. (Harahap, 2009) revealed that the current employee of Islamic banking and finance industries not fulfilling the demand of industries and not able to apply sharia compliance in the banking practices. However, the industry should prepare as early as possible to prepare better human capital who understand well sharia aspects.

(Haneef, 1995) a Malaysian Islamic Economic thinker, argues that Muslim thinkers in the economy are divided into 3 (three) categories, namely (1) the legalistic-normative, ie, experts and scholars fiqh (Islamic law), (2) the modernist who are more willing to provide interpretations of Islamic teachings in order to answer the issues facing society today, and (3) the practitioner or the Muslim economists that Western educational background, which tried to combine economic approach to jurisprudence and Islamic Economics can be integrated. In other words, they tried to construct Islamic economy by reducing the values of conventional economic systems that are incompatible with Islam and Islamic value in economic analysis. 
According to (Edwin, 2009), there are only 20 universities taking the role of offering the Islamic economics program and merely around 1000 graduated annually. This statement strengthened the finding of (Jazuli, 2009) that estimated in 5-10 years ahead the industry demanding more than 38.940 graduates of Diploma and Doctor of Philoshopy. While within 10-30 years ahead, the estimated graduates is expected to be 125.790 graduates. In addition, at least 10 universities are expected to offer the Doctor of Philosophy program in the field of Islamic economics.

(Dantes, 2009) emphasized that curriculum is not just a list of subjects that are translated into a syllabus that can be taken directly from the table of contents. The curriculum should include philosophy (vision and mission), the purpose of education and content courses. The curriculum should also include the impact of the planned learning outcomes, in the form of competence, for the present and the future. The curriculum should include teaching methods, methods of assessment and evaluation, resources and expertise necessary.

(Hamalik, 2006) argues that simple way to consider the curriculum is to look at the curriculum at 4 (four) phases, namely the content, methods, goals (purpose), and evaluation. Curriculum-as a whole have components that are interrelated, namely (1) objectives, (2) material, (3) methods, (4) organization, and (5) evaluation. The curriculum assumed a very important role for the education of students. There are at least 3 (three) kinds of roles that are considered very important curriculum, namely (1) the role of conservative, (2) the role of critical-evaluative, and (3) creative role. These three roles are equally important and need to be applied in a balanced.

This study is considered as the new approach of evaluating the best model of education in Islamic economics and finance as it employs ANP. Therefore, this study produces neo-classical approach that combines quantitative as well as qualitative methods. Meanwhile, the huge gap between industries and academics in producing the most demanded graduates still remains unresolved whether in Indonesia and UK. 


\section{Methodology}

This study undertakes several steps that comply with ANP method. First, in order to comprehend the holistic problems, FGD (Focus Group Discussion), in-depth interview and questionnaire will be conducted with all stake holders of education in Islamic economics and finance in these countries. Second, conduct pair-wise comparison and lastly synthesis to produce solution. This study comprises of several steps undertaken prior to generating the best solution and the most possible strategy of educational model in Islamic finance and economics. In line with this, the research stage is conducted as depicted by the following picture:

Picture 1 Research Stages

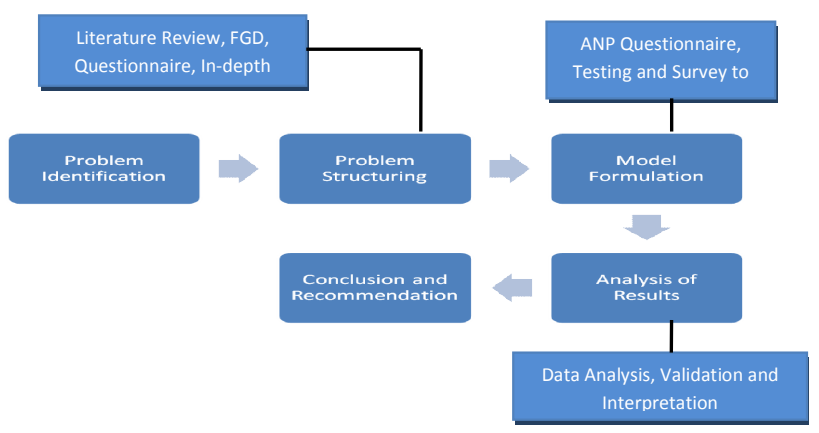

In the first step, prior to problem structuring, problem identification is necessary to comprehend the overall problem of generating the best model of education in Islamic finance and economics. The next step is structuring all related problems by way of undertaking literature review, conducting FGD (Focus Group Discussion), disseminating questionnaire and in-depth interview. The next step is formulating the model of ANP by testing pair-wise comparison according to ANP network. In order to analyze the result, synthesis and data processing through ANP software is conducted and the last step is producing conclusion and recommendation. 


\section{ANP Network}

In line with problem identification, the concept of ANP network is designed as follow:

Picture 2 ANP Network

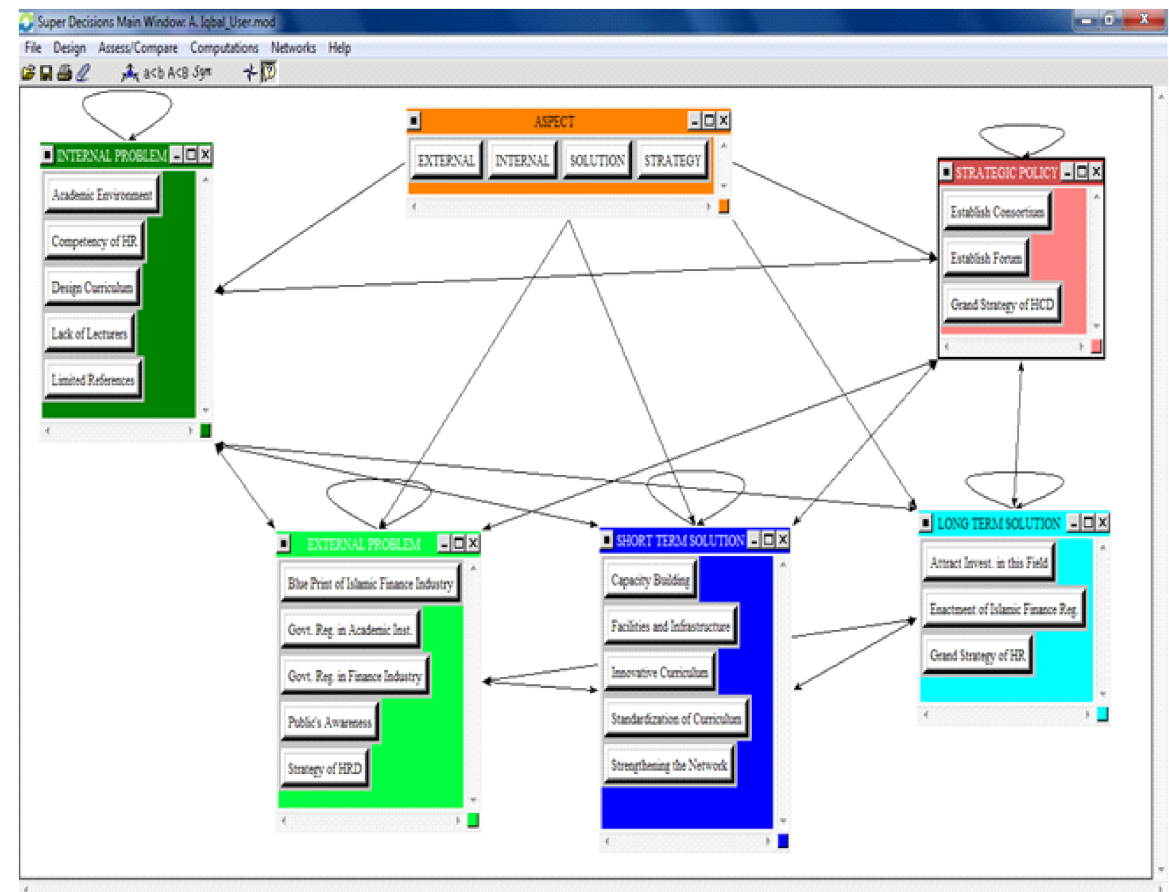

\section{Problem Identification}

Prior to problem identification and in line with the process of problems structuring (questionnaire, in-depth interview, FGD, Seminar), the clusters are grouped into problem (internal and external), solution (short term and long term) and strategic policy as outlined as follows:

\section{Internal Problem}

1) Limited references. Islamic finance and economics is considered as an infant industry amid the rapid growth of banking sector in any country across the world. Therefore, it is not surprising when the availability of references particularly in academic institution 
becomes barrier to students to explore more knowledge in this area. It is considered as an internal problem since both countries according the experts and academicians of both countries lacking the required references that result insufficient knowledge of this area. 2) Lack of lecturers. Human capital in the area of Islamic finance and economics remain serious problem facing both countries. The result of questionnaire and based on discussion conducted in both countries revealed that they are lacking of capable lecturers who are able to demonstrate the skill and knowledge of Islamic finance and economics. Indonesia and UK interestingly showed different phenomenon in meeting the demand of industry by recruiting talented lecturers who possess relevant background whilst universities in both countries providing different curriculum that meet the need of industry. 3) Design curriculum. Indonesia possesses different academic culture compared to its counterpart. They used to have special workshop in designing an appropriate curriculum while UK seems to have pragmatism as long as such curriculum accepted by the industry. Interestingly, in terms of growth, UK has no serious problem in designing curriculum while Indonesia still experience sluggish academic culture since the dispute opinions among academicians over Islamic economics remain obstacle. 4) Competency of human resources. Certainly Indonesia based on relevant a study on this area shows that there are diversified competencies of human resources since the industries (Islamic banking and finance institution) have different business orientation. While in UK, the study shows no such problem in setting the competency of human resources that demanded by the industry. 5) Academic environment. The academic culture of both countries shows different as well since both located in different continent. This evidenced from co-curriculum activities that support their knowledge on Islamic economics and finance. Unlike United Kingdom, Indonesia has varieties of informal program instead of universities program like discussion, seminar, workshop, conferences including the association. Meanwhile, in UK, these activities not really attached with formal activities. The UK academic environment emphasizes to obtain the substance rather that formality as the way to pave the knowledge of Islamic economics and finance. 


\section{External Problem}

1) Public awareness. As geographical location of both countries differ, public exposure on Islamic economics and finance also exhibits different phenomenon as well. In Indonesia, the academic and industry integrate each towards strategic effort to create public awareness particularly muslim customers as dominating population and expected to contribute significantly to the industrial growth. In UK, public awareness is not driven by any institution rather individual awareness is the factor to contribute Islamic financial growth. Therefore, public awareness is born individually compared to Indonesia where institutions are taking part towards the public awareness. 2) Government regulation in academic institution. There varieties of program related to Islamic economics and finance offered by Indonesian universities compared to UK universities. This result in government regulation which seem to be similar in both countries. The difference merely in the accreditation of program offered by respective universities in both countries. 3) Government regulation in financial industry. The government regulation certainly possesses different characteristics since both countries implement different policies and supervision. Unlike UK, Indonesian banking and finance industry comprises of Sharia supervisory boards instead of board of directors which is compliant to regulation of National Sharia supervisory board while UK, the sharia supervision refers to International Sharia standards. 4) Strategy of human resource development. The strategy of human resource development in UK not really obvious compared to Indonesia. Indonesia government together with academic striving to prepare human resource development to expedite the growth of Islamic finance industry. 5) Blue print of Islamic finance industry. The term of blue print was not popular in UK. UK government has set up similar terms which have been initiated by UK Financial Services Authority. While, in Indonesia, the Directorate of Islamic Banking, Bank Indonesia, has more proper preparation in setting up the blue print which is aimed to oversee the regulation, supervision and risk management.

\section{Short Term Solution}

1) Facilities and infrastructure includes library, internet connection, and laboratory. According to experts in UK, facilities that support 
Islamic economics and finance considered as short term solution to be taken in every universities offering this program. This evidenced by commitment of universities to provide sufficient resources on this area as the students can access easily compared to Indonesia. In Indonesia, the universities offering this program are lacking of this facilities that create some constraints to the students. 2) Capacity building. In terms of capacity building, Indonesia and UK have similar pattern which is mostly capacity building conducted by non government organization. Therefore, capacity building is an integral part of short term solution as suggested by the respondents. 3) Strengthening the network with all stakeholders. Indonesia seems better atmosphere in terms of synergy among industries and academics as well as other relevant stake holders. This evidenced by the association of Islamic finance and banking industry together with academicians and publics. While in UK, this phenomenon does not prevail. 4) Innovative curriculum comprising subjects related to the current industrial needs. The innovation of curriculum is not really significant and obvious in UK. Innovation is defined as compliant to industrial need and seems to be simple where as Indonesia innovative curriculum varies according to the program offered in the sphere of Islamic finance and economics. However, based on interviews, innovative curriculum is another solution to overcome the problem of gap between industry and academic. 5) Standardization of curriculum who conduct Islamic finance and economics program. Both countries show no such standardized curriculum across the universities offering this program and hence, the idea of standardization according to the opinions of all respondent in both countries remains as short term solution.

\section{Long Term Solution}

1) Grand strategy of human resources that matched with industrial needs. It is no doubt that all respondents of both countries argued grand strategy of human resources to be considered as long term solution. The strategy of both countries would be different depending on the government's policy. 2) Attract investment in the field of Islamic banking and finance. The investment in this field found to be difficult and not encouraging in both countries. 
However, in UK the capital flow in the area of Islamic finance more tremendous compared to Indonesia. Therefore, investment in this sector considered as long term solution since it needs other factors influencing the investment. 3) Enactment of Islamic finance regulation. Indonesia has recently endorsed and legalized the Islamic banking act. However, the implementation is taking time as the government needs the public awareness. Meanwhile, the UK government not specifically mention Islamic banking act rather general act on banking as applied to conventional. Nevertheless, enactment of this regulation in both countries according to all respondents considered as long term solution.

\section{Strategic Policy}

1) Grand strategy of human resource development. Instead of solution, strategy of human resources also argued by all respondents of both countries to be the most strategic policy to expedite the growth of Islamic economics and finance industry and hence producing the best model of education in this area. 2) Establish forum among academicians and industry. In Indonesia they are many types of forum which is available not only in academic institution but also industry where as in UK the informal activities including forum among academicians and industry subject to government regulation. 3) Establish consortium of all stake holders ranging from practitioners, academicians, users, experts, regulators. The establishment of consortium is agreed among respondents of both countries as strategic policy to bridge the gap among them.

\section{Result and Analysis}

According to the result of ANP process, there are many aspects in order to have the best model of education in Islamic economics and finance in Indonesia and UK. The model encompasses problems, solution and strategies. In Indonesia, the main internal problem is competency of human resources (0.243), external problem is government regulation in financial industry (0.340), strengthening the network (0.281) is short term solution, the long term solution is enactment of Islamic financial regulation (0.416) and the best strategic policy is to establish forum and consortium (0.301). 
Meanwhile, for the case of United Kingdom, the internal problem is lack of lecturers (0.424) followed by strategy of human resource development as external problem (0.270), while innovative curriculum (0.312) is regarded as short term solution. The long term solution is grand strategy of human resource development (0.375) and the strategic policy is grand strategy of human resource development (0.603). The best model of education in Islamic economics and finance in both countries can be described by the following table:

Table : Summary of ANP Result

\begin{tabular}{|c|c|c|}
\hline ASPECT & INDONESIA & UNITED KINGDOM \\
\hline Internal Problem & $\begin{array}{l}\text { Competency of human } \\
\text { resources }\end{array}$ & Lack of lecturers \\
\hline External & $\begin{array}{l}\text { Government regulation in } \\
\text { financial industry }\end{array}$ & $\begin{array}{l}\text { Strategy of human } \\
\text { resource development }\end{array}$ \\
\hline $\begin{array}{l}\text { Short Term } \\
\text { Solution }\end{array}$ & $\begin{array}{l}\text { Strengthening the network } \\
\text { and innovative curriculum }\end{array}$ & Innovative curriculum \\
\hline Long Term & Enactment of Islamic & Grand \\
\hline Solution & gulation & resource development \\
\hline Strategic Policy & $\begin{array}{l}\text { Establish forum and } \\
\text { consortium }\end{array}$ & $\begin{array}{l}\text { Grand strategy of human } \\
\text { resource development }\end{array}$ \\
\hline
\end{tabular}

The above table evidenced that both countries demanding capable and talented human resources to bridge the gap between industries and academic institutions. In fact, it is considered as internal problem that should be resolved in the long term and applied as strategic policy in United Kingdom. Meanwhile, in Indonesia, strengthening the network between industries and academic institution remains as short term solution whilst enactment of Islamic finance regulation considered as long term solution. The strategic policy is to establish forum and consortium in order to resolve the barrier problem between two institutions.

\section{Conclusion}

The academic institutions of both countries adopt different model of education in Islamic economics and finance. This evidenced by the existence of program for post graduate and undergraduate in Islamic economics and finance adopting different syllabus and academic approach in both countries. The model of education 
developed in line with the need of industries in United Kingdom which is seem to have more simple compared to its counterpart Indonesia where all model of education in any level of degree adopted that in line with the epistemology of Islamic economics and finance as a science and discipline while industrial need not taken into account although some efforts undertaken by the government and academic institutions, but the gap between them remain constant. Since the emergence of Islamic finance industry, the need of human resource to meet the industrial needs remain unresolved problem.

This problem has been experienced by Indonesia and United Kingdom and even another part of the world who is undertaking Islamic finance and economics program in their respective countries. This phenomenon is proved by the result of ANP that lack of human resource remains the main problem in bridging the barrier between academic and industries. As result, the growth of Islamic finance and economics still remain sluggish. In addition, it is very interesting to note that, grand strategy of human resource development becomes the essential part of long term solution as well as strategy of UK in generating the best model of education in Islamic economics and finance compared to its counterpart where legality aspect (enactment of Islamic finance regulation) and establish forum and consortium considered as long term solution and strategic policy. This finding reveals that Indonesia and UK have different method in order to come up with the best model of education that might overcome the barriers between academic and industries.

\section{References}

Affandi, Akhmad, Performance of Islamic Commercial Banks in Indonesia after the Financial Crisis, Lambert Academic Publishing, Germany, 2011.

Ahmad, Abu Umar Faruq and M. Kabir Hassan, The Adoption of the UK Finance Bill Proposals on Islamic Finance into Islamic Banking in Australia, Review of Islamic Economics, Vol. 10, No. 1, 2006.

Ahmed, Salahuddin, Islamic Banking Finance and Insurance: A Global Overview, Kuala Lumpur: A.S. Noordeen Publishing, 2006. 
al Kasrie, Rahmatina, "Evaluating MBA Program in Islamic Banking and Finance: A Performance-Importance Analysis", The paper has been presented at The 2010 Oxford business and Economic Conference, St. Hugh Cllege, Oxford University, United Kingdom, 28-30 June 2010.

Amalia, Euis, et all., Potrait of Islamic Economics Education in Indonesia: Analysis of Curriculum, Learning Model and Its Relation to the HR Competency Islamic Finance Industry in Indonesia, Jakarta: Gramata Publishing, 2010.

Anna, CRAFT, Creativity Across The Primary Curriculum : Framing And Developing Practice, London: Routledge, 1999.200

Anonymous, "Menggodok Kurikulum-Menyiapkan SDM Andal (Preparing Quality Curriculum and Qualified Human Resource)", Majalah Sharing, Jakarta: April Ed., 2009.

Anonymous, "SBY: Jadikan Pengembangan Ekonomi Syariah Agenda Nasional", Suara Karya, Thursday January 17, 2008.

Arifin, Zainul, Bank Syari'ab: Lingkup, Peluang, Tantangan dan Prospek (Sharia Bank: Scoup, Opportunities, Challenges and Prospect), Jakarta: Alvabet, 2003.

Ascarya, "Analytic Network Process (ANP): Pendekatan Baru Studi Kualitatif" (Analytic Network Process (ANP): A New Approach for Qualitative Research), PPSK Central Bank of Indonesia, 2005.

Dantes, Nyoman "Kurikulum Berbasis Kompetensi di Perguruan Tinggi (Competency-Based Curriculum in Higher Education)", paper presented at the Workshop on Curriculum Faculty of Art and Design, Art Institute of Indonesia, Denpasar, November 18, 2009.

DC McClelland, "Testing for Competence rather than for intelligence", American Psychologist, Vol. 28, No. 1, American Psychological Association, 1973.

Decision of the Director General of Higher Education Ministry of National Education No. 44/DIKTI/Kep. /2006 about Signs-Signage Implementation Subjects Bohemian community in High Lectures.

Departemen Luar Negeri dan Persemakmuran London, Muslim Inggris, Jakarta: Departemen Luar Negeri dan Persemakmuran London, 2009.

Mulyasa, E., Kurikulum Berbasis Kompetensi: Konsep $\&$ Karakteristik (Curriculum Based of Competence: Concept and Characteristic), Bandung: Rosdakarya, 2004. 
Enders, W. Applied Econometric Time Series, Canada: Willey \& Sons, 1995. Farooq, Syed Umar et all, An Analytical Study of the Potential of Takaful Companies, European Journal of Economics, Finance and Administrative Sciences - Issue 20, 2010.

Fry, Heather, Steve Ketteridge and Stephanie Marshall, A Handbook for Theaching \& Learning in Higher Education, Second Edition, Kogan Page Publishing, 2003.

Fuad, Noor, Ghofur Ahmad, Integrated Human Resources Development, Jakarta: Grasindo, 2009.

Gomes, Faustino Cardoso, Human Resource Management, New York: Andi Publishers, 2003.

Gujarati, Damodar, Basic Econometrics, $3^{\text {rd }}$ Edition, New Yorks: McGraw Hill, 1995.

Hadari, Nawawi, Evaluasi dan Manajemen Kinerja di Lingkungan Perusahaan dan Industri (Evaluation and Performance Management in the Environmental and Industrial Company), Yogyakarta: Gadjah Mada Univesity Press, 2006.

Hamalik, Oemar, Manajemen Belajar di Perdosenan Tinggi, Bandung: Sinar Baru Algensindo, 2003.

Hamalik, Oemar Manajemen Pengembangan Kurikulum (Curriculum Development Management), Bandung: Program Pascasarjana UPI dan PT Remaja Rosdakarya, 2006.

Hamalik, Oemar Proses Belajar-Mengajar (Process of Learnig), Jakarta: Bumi Aksara, 2003.

Haneef, Mohamed Asalam, Contemporary Islamic Economic Thought: A Selected Comparative Analysis, Kuala Lumpur: S. Abdul Majeed \& Co., 1995.

Hendyat, Sutopo, Pembinaan Dan Pengembangan Kurikulum : Sebagai Substansi Problem, Jakarta: Bina Aksara, 1986.

Herman, Darnel, Pengembangan Kompetensi SDM Di PT. Indonesia Power: Apa, Mengapa, dan Bagaimana? (HR Competency Development at PT. Indonesia Power: What, Why, and How?), Paper presented at the ICM Interactive Discussion MKI in Suralaya, October 14, 2000.

Ismail, Rifki "Pendidikan Ekonomi dan Keuangan Islam di Inggris", Makalah disampaikan dalam Workshop Arsitektur Ilmu Ekonomi Islam ("The Education of Islamic Economy and Finance in UK - a paper presented at the workshop entitled 
the architecture of Islamic Economics), January 28, 2012.

Jihad, Asep Abdul Haris, Evaluasi Pembelajaran, Yogyakarta: Multi Pressindo, 2010.

Kahf, Monzer, The Islamic Economy: Analytical Study of the Functioning od the Islamic Economic System, T.tt.: Plainfield In Muslim Studies Association of U.S-Canada, 1978.

Keputusan Direktur Jenderal Pendidikan Tinggi Departemen Pendidikan Nasional RI No. 44/DIKTI/Kep./ 2006 tentang Rambu-Rambu Pelaksanaan Mata Kuliah Berkehidupan Bermasyarakat di Perdosenan Tinggi.

Lunati, M. Teresa, Ethical Issues in Economics: From Altruism to Cooperation to Equity, London: Mac Millan Press, 1997.

Malik, Rizwan, Islamic Finance Country Index 2012, Islamic Finance Riview (ISFIRE) Volume 2, Issue 2, May 2012.

Miarso, Yusufhadi, Pembelajaran di Perguruan Tinggi : Isu-isu Aktual Saat ini (Learning, in Higher Education: Currently Issues), paper was presented at the August 28, 2006.

Mirakhor, Abbas, A Note on Islamic Economics, IDB Prizes Winner, Lectures Series No 20, IRTI IDB, Jeddah, 2007.

Mirza, Abdul Malik and Abdel-Karim Halabi, Islamic Banking in Australia: Challenges and Opportunities, Journal of Muslim Minority Affairs, Vol. 23, No. 2, October, 2003.

Muqarrobin, Masyhudi "The Development of Curriculum and Silaby on Islamic Economics Departement at Muhmmadiyyah Universities: An Offering”, paper, presented on Islamic Economics Curriculum Workshop at Tazkia College, P3EI UII Jogjakarta and University of Muhammadiyah Forum, 2010.

Nasution, S., Asas-Asas Kurikulum (The Fundamental of Curriculum), Jakarta: Bumi Aksara, 2001.

Personnel Directorate General for Quality Improvement of Teachers and Education Personnel, Ministry of Education, Strategi Pembelajaran dan Pemilihannya (Learning Strategies and the selection), Jakarta: Depdiknas, 2008.

Rahardjo, Dawam, Islam dan Transformasi Sistem Ekonomi (Islam and Transformation of Economic System), Jakarta: LSAF, 2006.

Ramadhani, Neila, Active Learning dan Softskills, paper was presented at the seminar "Leveraging Soft Skills for Learning", Yogyakarta: Panti Rapih AKPER, March 14, 2008. 
Rivai, Veithzal and Ella Jauvani Sagala, "Manajemen Sumber Daya Manusia untuk Perusahaan (Human Resource Management for Enterprise)", Jakarta: Rajawali Press, 2009.

Rusman, Manajemen Kurikulum (Curriculum Management), Jakarta: RajaGrafindo Persada, 2009.

Saaty, Rozann W., Decision Making in Complex Environments: The Analytic Network Process (ANP) for Decision Making with Dependence and Feedback, Creative Decisions Foundation, Pittsburgh PA 15113, 2003.

Saaty, Thomas L, "Fundamentals of The Analytic Network Process", ISAHP, Journal, August 12-14, Kobe, Japan, 1999.

Saaty, Thomas L, Decision Making with Dependence and Feedback: The Analytic Network Process, RWS Publications, 4922 Ellsworth Avenue, Pittsburgh, PA. 15213. 1996.

Saaty, Thomas L, The Analytic Network Process, RWS Publications, 4922 Ellsworth Avenue, Pittsburg, PA 15213, 1997.

Sadili, Samsudin, Human Resource Management, New York: Faithful Reader, 2006.

Setiadi, Edi, "Krisis SDM di Perbankan Syariah (the crisis of Human Resource at Islamic Banking)", Diskusi Ramadhan Forum Jurnalis Ekonomi Syariah (the Ramadhan Discussion of Islamic Banking Journalist Forum), Jakarta, August 19, 2012.

Siddiqi, Muhammad N., Muslim Economic Thinking: A Survey of Contemporary Literature. Jeddah and The Islmic Foundation, 1981.

Suharno, "Reorientasi Pengembangan Kurikulum di Perguruan Tinggi (Reorientation of Curriculum Development in Higher Education)", AKADEMIKA Journal, Vol. 1 No. 1, Januari 2009, p. 2, published by Universitas Negeri Solo (UNS).

Suparman, M. Atwi, Konsep Dasar Pengembangan Kurikulum (The Fundamenal Concept of Developed Curriculum), Jakarta: PAU-PPAI-Univ.Terbuka, 2001

Tim PEKERTI-AA PPSP LPP Universitas Sebelas Maret, Panduan Pengembangan Kurikulum (Curriculum Development Guide), Surakarta: Universitas Sebelas Maret, 2007.

Treasury, HM, The Development of Islamic Finance in the UK: The Government's Perspective December 2008.

Widoyoko, Eko Putro, Evaluasi Program Pembelajaran: Panduan Praktis bagi Pendidik dan Calon Pendidik, Yogyakarta: Pustaka Pelajar, 2009. 